Journal of

APF Command and Staff College

\title{
Dichotomies in Understanding of Peace in Nepal
}

\author{
Rajib Timalsina \\ Assistant Professor of Conflict, Peace and Development Studies at Tribhuvan University \\ rajib.timalsina@gmail.com
}

Article History

Received September 30, 2020

Accepted October 21, 2020

Keywords Peace, Peace

Studies, Conflict and Peace,

Peace Education, Peace

Philosophy in Nepal

Corresponding Editor

Ramesh Raj Kunwar

kunwar.dr@gmail.com

\begin{abstract}
In Nepal, the decade long armed conflict between 1996 and 2006 has become the buzz word in most social sciences literatures. Since 2007, 'peace' has emerged as essential component of the academic courses and training manuals. Against this backdrop, this paper focuses on the understanding of "Peace" in local context of Nepal. This paper compares the various definitions of peace from western and eastern intellectual perspectives, examines the literatures on how they depict Nepal's peace process, and includes a brief history of peace studies as discipline in Nepal. Methodologically, this is a reflection based paper evolved from qualitative eclectic approach. The researcher has used axial coding and domain analysis. This paper concludes that the epistemological roots of conflict and peace studies are under-researched in Nepali context. The influence of Maoist armed conflict is very dominant in peace studies literatures which have missed to produce the comparative-historic indigenous writings on Nepal.
\end{abstract}

Copyright@2021 Author

Published by: APF Command and Staff College, Kathmandu, Nepal

ISSN 2616-0242 


\section{Context}

Nepal experienced a decade long armed conflict and ended with the comprehensive peace accord in 2006. Even after the official end of the armed conflict, Nepal observed various political instability and notable civil unrests. The diverse ethnic and minority groups have been calling for inclusion in mainstream politics which were linked to provisions of the peace agreements and constitution writing process. In 2015, in response to a long instability, Nepal became a federal state with a number of powers devolved to 753 new local governments have received several important powers; including regulating education andhealth care(Timalsina, 2017:70). Afterthenew constitution, Nepal's politics has become more stable. Nepal was featured for low economic growth, social inequality, limited development progress and widespread poverty over the 20 years in various literatures. Nepal's economic growth has only grown between $2 \%$ and $4 \%$ per year, which reached $6 \%$ to $7 \%$ in late 2010 s until the COVID-19 pandemic hit the economy (Nepal Rastra Bank, 2020). Now the national conversation has been dominated by state restructuring around the constitutional provisions, access to basic services and civic and political participation.

Since 2007, 'peace' has emerged as essential part of the national school curriculum, university courses and the training manuals of the civil society organizations. It is evident that the concept itself is trying to serve the immediate need of the post-conflict society. Referring to the several conversations with Prof. Dr. Ramesh Raj Kunwar, former Dean at Faculties of Humanities and Social Sciences, Tribhuvan University, Nepal has 'concept' of peace in curriculum, but it has rarely captured our indigenous notion of peace. The long-rooted and historical notion of the peace in Nepali society has been undermined. He further argues the classes and scholars teaching 'peace' had hardly understood the historical pedagogical approaches and the resources from Nepali culture. Thus, it can be claimed that the epistemological roots of conflict and peace studies are under-researched in Nepali contexts and there is need of more empirical knowledge production in the discipline of peace studies (Kunwar, 2018).

These contextual information set rationale for more and better study to diagnose how the understanding of 'peace' exists in Nepal. This paper focuses to analyse understanding of peace in Nepali context.

This paper has 6 sections. The first section discusses the brief country context and introduction. The second section includes methodological approaches. The third section explains the various definitions of peace from diverse perspectives. The fourth section has analysed how 'Nepal's peace process' has been portrayed in literatures. The fifth section includes a brief paragraphs on the evolution of peace studies as a discipline in Nepal. The final section concludes the paper. 


\section{Methodology}

This paper makes the case how a concept 'peace' has been explored in Nepal. The aim of the paper is to present the views of a wide variety of stakeholders and draws on lessons from literatures. The research paper is based on the findings of a study carried out in Nepal in 2017-2019. A major rationale behind the study was to counter the existing viewpoints that the academia and researchers are using the 'peace' as a new concept and mostly only linking to Maoists Armed conflict which undermines the thousands years of existence of 'peace' concept in Nepali societies.

Collating the observations of publications of 'peace studies' in Nepal, reviewing the existing curriculum of peace studies courses, and notes from more than 7 semi-structured conversations with Nepali academics and locals, this paper examines considerations in the understanding the term 'peace' in Nepal's context. The researcher has used axial and emergent coding and domain analysis approach of qualitative research design to develop this paper. This is more a reflection based paper developed from qualitative eclectic approach. "Eclectic research is a strategy that tries to demonstrate that the findings from a study have construct validity (Armstrong, 1974)", and it refers to the practice of deriving ideas, generalized knowledge, or research conclusion based on a broad and diverse range of sources (Kunwar, 2015).

\section{Understanding of peace in diverse perspectives}

"The Sanskrit verse of Vedic text, Shanti Path of Hindu scripts demands peace in the universe including the heaven or sky very nook of the cosmic space, the earth and the vegetative world, herbal world, and everywhere... (Kunwar, 2010: 299)." Ramesh Raj Kunwar (2010: 299) further quotes the Vedic verse:

"Om dyauh shantir-antariksa-m shantih,

Prithivi shantir apah shantir osa-dhyah shantih,

Vanaspatayah shantir vis-ve-devah shantih,

\section{Brahma shanti savam shantih shantireva shantih sama shantiredhi ||”}

This Vedic text reflects the understanding of peace from the oldest written script of the world. Consequently, Johan Galtung, a founder of peace studies in Europe, has, among others, defined 'peace' by distinguishing "positive" and "negative" peace. Galtung is one scholar highly cited in the curriculum of peace studies in Nepal, mainly in the introduction part of peace studies. Galtung (1996) defines peace from two compatible definitions:

"Peace is the absence/reduction of violence of all kinds". and, "Peace is nonviolent and creative conflict transformation (Galtung, 1996)”. 
Galtung himself explains what purposes his definitions serve. "For both definitions, in one, peace work is work to reduce violence by peaceful means. And in another, a peace study is the study of the conditions of peace work. The first definition is violence-oriented; peace being its negation. To know about peace we have to know about violence. The second definition is conflict-oriented; peace is the context for conflicts to unfold nonviolently and creatively. To know about peace we have to know about conflict and how conflicts can be transformed, both nonviolently and creatively. Obviously this latter definition is more dynamic than the former (Galtung, 1996)".

In nutshell, the definition of peace from Galtung, "positive" peace denotes the simultaneous presence of many desirable states of mind and society, such as harmony, justice, equity, and so on. "Negative" peace has historically denoted the "absence of war" and other forms of large-scale violent human conflict (Galtung, 1969). The majority of the western scholarships on 'peace' connect their definitions with the nature of conflict and violence in some way or another. Here is a table which compiles multiple definitions of 'peace' and the concepts underlying.

\begin{tabular}{|c|c|c|}
\hline Authors & Definitions of Peace & Key Words/Concepts Focused \\
\hline T. Shaikh (2016) & $\begin{array}{l}\text { "For me personally speaking, I } \\
\text { felt absolutely peaceful when I'm } \\
\text { writing or when I'm spending } \\
\text { time with my kids To me the word } \\
\text { "peace" means me being in alignment } \\
\text { with what I was put on this earth } \\
\text { to do. I feel so peaceful at those } \\
\text { moments, and feel absolutely out } \\
\text { of place when I'm doing something } \\
\text { that is against my core and inner } \\
\text { values." }\end{array}$ & $\begin{array}{lr}\begin{array}{l}\text { More personal } \\
\text { oriented }\end{array} & \begin{array}{r}\text { feelings } \\
\text { definition. }\end{array} \\
\text { Related to intra-personal peace. }\end{array}$ \\
\hline $\begin{array}{l}\text { Purvi Shahpatel } \\
(2016)\end{array}$ & $\begin{array}{l}\text { Peace comes from having unity, } \\
\text { kinship, and harmony with those } \\
\text { around you. }\end{array}$ & $\begin{array}{l}\text { This is more dealing with } \\
\text { inter-personal relationship. } \\
\text { Connection between person } \\
\text { to person is very important. }\end{array}$ \\
\hline $\begin{array}{l}\text { Debbie Jones } \\
\text { (in Shaikh, 2016) }\end{array}$ & $\begin{array}{l}\text { Peace is when you love yourself } \\
\text { enough to forgive others around } \\
\text { you. }\end{array}$ & $\begin{array}{l}\text { This definition tries dealing } \\
\text { with both the intra-personal } \\
\text { and inter-personal peace. }\end{array}$ \\
\hline $\begin{array}{l}\text { Kinjal Amin } \\
\text { (in Shaikh, 2016) }\end{array}$ & $\begin{array}{l}\text { My definition of peace: The first } \\
\text { word that comes to my mind is } \\
\text { "calm." It's that feeling to be } \\
\text { able to breathe the air and tell } \\
\text { myself, "I can do whatever I } \\
\text { desire to do." To me, it's a value to }\end{array}$ & $\begin{array}{l}\text { This definition has focused on } \\
\text { individual freedom, intra-per- } \\
\text { sonal feeling, and inter-personal } \\
\text { relationship. }\end{array}$ \\
\hline
\end{tabular}




\begin{tabular}{|c|c|c|}
\hline & $\begin{array}{l}\text { express myself among others' } \\
\text { opinions without any conflict. } \\
\text { A result of an understanding by } \\
\text { absorbing the differences in a } \\
\text { healthy manner is what I call peace. }\end{array}$ & \\
\hline $\begin{array}{l}\text { Sara Scmit } \\
\text { (in Shaikh, 2016) }\end{array}$ & $\begin{array}{l}\text { Peace will be when everything } \\
\text { around us stops and we live in the } \\
\text { moment. }\end{array}$ & $\begin{array}{l}\text { This is more about the calmness } \\
\text { and silence around a person. } \\
\text { More intra-personal feeling. }\end{array}$ \\
\hline $\begin{array}{l}\text { Amarah Gillani } \\
\text { (in Shaikh, 2016) }\end{array}$ & Peace means positivity. & $\begin{array}{l}\text { This is referring to positivity as } \\
\text { feeling. }\end{array}$ \\
\hline $\begin{array}{l}\text { R.K (in Shaikh, } \\
\text { 2016) }\end{array}$ & $\begin{array}{l}\text { To be at peace means to accept } \\
\text { everything around you, I am never } \\
\text { at peace as there is so much around } \\
\text { me that needs to be changed. }\end{array}$ & $\begin{array}{l}\text { This definition is more } \\
\text { submissive and trying to adapt in } \\
\text { the situation without changing it. }\end{array}$ \\
\hline $\begin{array}{l}\text { Mary Frasner } \\
\text { (in Shaikh, 2016) }\end{array}$ & Peace is when my heart is happy. & Focusing on happiness. \\
\hline $\begin{array}{l}\text { International Alert } \\
(2019)\end{array}$ & $\begin{array}{l}\text { Peace is when people are able to } \\
\text { resolve their conflicts without } \\
\text { violence and can work together to } \\
\text { improve the quality of their lives. }\end{array}$ & $\begin{array}{l}\text { Non-violence, quality of life, } \\
\text { and conflict resolution }\end{array}$ \\
\hline $\begin{array}{l}\text { Jonathan Armando } \\
\text { (in Shaikh, 2016) }\end{array}$ & $\begin{array}{l}\text { Peace can only be found in the } \\
\text { small corners of my own self, } \\
\text { I can look around me and think } \\
\text { someone else will give it to } \\
\text { me but that's not how it works. }\end{array}$ & $\begin{array}{l}\text { This is more about the inner } \\
\text { feelings. }\end{array}$ \\
\hline $\begin{array}{l}\text { Noor Khan } \\
\text { (in Shaikh, 2016) }\end{array}$ & Love is peace. & $\begin{array}{l}\text { Focusing on another vague } \\
\text { concept, love. }\end{array}$ \\
\hline $\begin{array}{l}\text { Webster's Third } \\
\text { New International } \\
\text { Dictionary }\end{array}$ & $\begin{array}{l}\text { Peace is initially defined as } \\
\text { "freedom from civil clamor and } \\
\text { confusion" and positively as } \\
\text { "a state of public quiet."Web- } \\
\text { ster's proceeds further to define } \\
\text { (political or outer) peace } \\
\text { positively as "a state of security } \\
\text { or order within a community } \\
\text { provided for by law, custom, } \\
\text { or public opinion." }\end{array}$ & $\begin{array}{l}\text { This definition focuses on the } \\
\text { freedom, inner feelings, and law } \\
\text { and social order. }\end{array}$ \\
\hline $\begin{array}{l}\text { D. P. Barash and } \\
\text { C. Webel (2018) }\end{array}$ & $\begin{array}{l}\text { Peace, like many theoretical } \\
\text { terms, is difficult to define. Like } \\
\text { happiness, harmony, justice, and } \\
\text { freedom, peace is something we } \\
\text { often recognize by its absence. }\end{array}$ & $\begin{array}{l}\text { This is focusing on the binary } \\
\text { definition as absence of war/ } \\
\text { conflict. }\end{array}$ \\
\hline
\end{tabular}




\begin{tabular}{|l|l|l|}
\hline $\begin{array}{l}\text { Oxford for Lexico } \\
\text { Dictionary }\end{array}$ & $\begin{array}{l}\text { Freedom from disturbance; } \\
\text { tranquility. and a state or period } \\
\text { in which there is no war or a war } \\
\text { has ended. }\end{array}$ & $\begin{array}{l}\text { Freedom and absence of war/ } \\
\text { conflict. }\end{array}$ \\
\hline $\begin{array}{l}\text { Anderson Royce } \\
(2009)\end{array}$ & $\begin{array}{l}\text { Peace is defined as a two- } \\
\text { dimensional construct with both } \\
\text { objective and subjective } \\
\text { measures that must be } \\
\text { studied within specific micro to } \\
\text { macro contexts. This intends to } \\
\text { create just and stable society. }\end{array}$ & \\
\hline $\begin{array}{l}\text { Bushra Siddiqa } \\
\text { (in Shaikh, 2016) }\end{array}$ & $\begin{array}{l}\text { For me the most vital is one's } \\
\text { inner peace. Where mind and body } \\
\text { is relaxed and life is wonderful. }\end{array}$ & $\begin{array}{l}\text { The definition focused on the } \\
\text { inner peace and intra-personal } \\
\text { feeling. }\end{array}$ \\
\hline
\end{tabular}

Source: Compiled by the Author, 2020.

The list of definitions summarizes the focus of 'peace' on intra-personal feeling, inter-personal relationships, individual freedom, love, happiness and absence of violence. Most of the definitions in the western scholarships refer to structural issues and individual human behaviour which was also the core at Galtung's defining. Whereas the oldest definition of peace from Hindu Vedic verse envision universal order, sustainable ecosystem and dignified human relations.

Similarly, the Chinese literatures are also rich and rooted of many social concepts. A Chinese philosopher Lao Tzu from 6th century BC, who is also the founder of Taoism, emphasized that military force is not the way for human beings to follow. He frequently referred to peaceful images of water or wind-both of them soft and yielding yet ultimately triumphant over such hard substances as rock or iron. The teachings of Confucius (approx. $500 \mathrm{BC}$ ) focus on the respect for tradition, including elders and ancestors (Barash \& Webel, 2018). Lucian W. Pye (1985) argues that Confucius valued obedience and order as virtues in themselves. For Confucius, peace came from social harmony and equilibrium. One famous quote of Confucius is, "Treat your subordinates as you would like to be treated by your superiors (Pye, 1985). Similarly, Barash and Webel (2018) mention a renowned ancient Chinese philosopher, Mo Tzu (468-391 BC), who took a different perspective. Mo Tzu argued against war and in favor of all-embracing love as a universal human virtue and the highest earthly goal, yet one that is within the grasp of each of us. He said, "Those who love others will also be loved in return. Do good to others and others will do good to you. Hate people and be hated by them. Hurt them and they will hurt you. What is hard about that? (Barash \& Webel, 2018)"

India also has a rich history of civilization. Emperor Ashok's life story is very interesting who established himself as a great warrior king, and renowned for abandoning his successful military campaigns in the middle of his career. The conversion of warrior king to a Buddhist monarch and devoting to the nonviolent means is remarkable incident. 
Bharatbarsha has lots of mythic account of vicious civil wars in the ancient Vedic Hindu texts such as Ramayana, and Mahabharat. The teachings of Bhagvat Geeta justifies war to maintain social order. When the main warrior Arjun was reluctant to fight after seeing many of his relatives on the opposing side, the god Krishna persuaded Arjun by reminding his selfless duty.

Mahatma Gandhi has often quoted in his book Hindha Swaraj as a metaphor how an individual person should de-emphasize individual self in the pursuit of common public goods (Gandhi, 1938). For Gandhi, it is important to have the public goods, social order and conscious peace as target for individuals.

In Christian Old Testament, The God of Abraham, Moses, and David are frequently portrayed as bloodthirsty. The ancient Israelites were glorified as merciless warriors. The prophet Isaiah, who praised the reign of peace and many Hebrew prophets tried to portray Jewish tradition to strongly endorse peacefulness. In fact, Jewish, Christian, Islamic, and Hindu traditions all have violence components and elements in their history.

Ultimately, we can observe the diverse ways of thought process on how the scholars define the 'peace'. Some scholars or writings have tried to justify violence to bring peace, on the other hand, some literatures focuses on the feelings and peace values which can not be attained through the means of violence or discriminations. The social justice and humanism are very essential elements in many recent writings. Albert Einstein has said, "We need an essentially new way of thinking if mankind is to survive. Men must radically change their attitudes toward each other and their views of the future. Force must no longer be an instrument of politics.... Today, we do not have much time left; it is up to our generation to succeed in thinking differently. If we fail, the days of civilized humanity are numbered (Barash \& Webel, 2018).”

\section{Idea of peace and Nepal's peace process portrayed in literatures}

In literatures, when talking about the peace process, Nepali youth are often targeted and perceived as instigators during conflicts, and their roles as peace-builders go unrecognized (Shrestha \& Jenkins, 2019). The academic and non-academic courses have included peaceand conflictresolution as animportantelementin post-2007 period, butoftenthe educators lack pedagogical approaches and resources for this purpose. Majority of theories, knowledge and teaching methods in conflict and peace studies, be it at universities or in schools, are borrowed from the western scholarships. Such approaches are often not adapted to local contexts. Without knowing the local knowledge base, it's almost impossible to address the structural exclusion and conflict-affected contexts. We know that the academic and research based knowledge serve the worldview of the researcher or the geographical region or socio-cultural aspects of researched area.

In this section, the author is trying to examine what is the way of explaining ideas of peace from Nepal. For that, in this section, the author tried to explore various literatures in order to see how those literatures have portrayed peace or peace process in Nepal. Nepal has 
been portrayed as rich in culture, history and civilization in multiple social literatures. The history of Nepal is also full of upheavals, conflicts, dispute resolutions, local mechanisms, indigenous practices, cultural ways of dealing with disputes and differences, and various interesting facts evolved through the civilization process of hundreds of ethnic and cultural groups. Here the author has compiled 5 examples of literatures to show how they have portrayed the peace process of Nepal. The first example is from a introductory paragraph of a material from Peace Direct:

"Known for its natural beauty and natural resource-rich and blessed with the highest peaks in the world for tourism, Nepal is often classified as a poor country working through the legacy of its decade-long internal armed conflict (1996-2006). The armed conflict claimed the lives of 17,000 people and displaced an estimated 100,000 more. The conflict was ended in 2006 when the democratic political parties and the Maoist's brought about the end of a 240-year old monarchy and established a republic in Nepal (Peace Direct, 2020)."

There are more than 20 Nepali civil society organizations are part of Peace Direct and referring these literature in their courses. The literature starts with the explanation of beautiful feature of the country and then, directly jumps into the 10 year long Maoist armed conflict and its consequences to explain the peace process of Nepal.

The second example is borrowed from concluding section of the article "Resource Conflicts and Conflict Resolution in Nepal” by Dr. Bishnu Raj Upreti.

"Though from the resource conflict point of view, Bishnu Raj Upreti claims "Resource conflicts are an inevitable part of Nepalese society. Their causes include hierarchical and patron-client social relations, the incompatibility of formal laws, conflicts of interest, perception and belief, competition over scarce resources, ambiguity over roles and responsibilities, the unwillingness of the state to respond to social, economic, political and technological changes, corruption, and bad governance. The present study analyzes resource conflicts and practices used to resolve them in Nepal... It concludes that existing, legally engineered formal conflict resolution systems are administratively complicated, expensive, elitist, heavily influenced by money and power, non-transparent, and inaccessible to the poor, and are therefore hardly adequate to address growing conflicts in $\mathrm{Ne}$ pal. Likewise, informal systems are also distorted and inherently biased towards those with power. Modernization of existing formal conflict resolution systems is urgently needed in Nepal (Upreti, 2009)."

Upreti claims that the formal justice system in Nepal is complicated, expensive and within reach of certain higher class only. At the same time, he also criticized the informal mechanism as biased and distorted. Then he recommends modernizing the formal justice system. When he is arguing both formal and indigenous systems have drawbacks, but he is strongly lobbying for the borrowing modern- developed by westerners rather than improving the indigenous and contextual systems to remove the biasness and to increase the ownership of indigenous communities. 
The third example of literature is taken from a policy brief of Nepal Institute for Policy Studies.

"Nepal passed through a decade long (1996-2006) violent conflict as a consequence of which Nepali people suffered severe threats to their state of political, social, economic, psychological and physical well being. The year 1996 marked the beginning of the armed conflict as the Communist Party of Nepal (Maoist) [CPN (Maoist)] launched the 'People's War' against the state.... The Twelve-Point Agreement signed by the Seven-Party Alliance (SPA) and the CPN (Maoist), on 22 November 2005 along with the subsequent popular peaceful movement of April 2006 brought an end to the decade-long armed conflict.... Although peace process has concluded, there are many challenges threatening the longevity of peace and development. Inability of the stakeholders in forming the TRC and the Commission for Disappeared Persons, lack of financial transparency and accountability of the process, failure in being all inclusive and sensitive to issues of women, children, dalits and other minorities, disabled and ex-combatants, inability to return the many seized lands to their rightful owners are major drawbacks of the peace process that continue to threaten overall peace and prosperity of the country (Nepal Institute for Policy Studies, 2013)."

The policy brief only discusses about the Maoist armed conflict 1996-2006 and aftermath events. The title of the policy brief reads as Nepal's Peace Process: A Brief Overview, it fails to give examples of various ways of peace promotions, peace processes of different time period in Nepal. It also doesn't compare the recent example of peace process with the historical one. Of course the authors are free to only include the recent one. Its better to entitle them in such a way that it reads as a case study of one particular peace process rather showing it a generalized version of peace processes in Nepal.

The fourth example is taken from the book written by Vidyadhar Mallik in 2013. The book starts with introduction which includes sections on: A country in transition; resolving the major contested issues; Scope of the book; the line of argument; and Governance for peace and development. The second section talks about the political instability in Nepal since the Maoist armed conflict. The third section discusses the peace process from 2008 to May 2012, the movements related to the ethnic and identity issues, and the politics of the dissolution of the Constituent Assembly. Another section deals with the peace process after May 2012 in Nepal. It further discusses the legacies of political instability in Nepal and the declining quality of governance including the limited progress on decentralized governmentand the poor economic growth. While the entire book says it aims to discuss peace, development and governance in Nepal, the book only revolves around the Maoist armed conflict, and then the successes and failures in the aftermath of post-conflict time.

The fifth example is taken from Chandra D. Bhatta's "Antinomies of Democracy and Peace in Nepal". Bhatta has focused on peace from democracy perspective. Though he clearly does not argue about the liberal democracy, most of his arguments are seemed to be influenced by the liberal peace theory. The summary section of his book chapter reads: 
"Does the regime established on the basis of popular movement always contribute toward peacebuilding and strengthen the democratization process? If it does, what are the necessary ingredients for that? This chapter deals with the case of Nepal where frequent regime changes, by using so called popular movements, have paralyzed the country. It appears that a practice has been established wherein every comfort, discomfort, approval, disapproval or breach of law either by the state or non-state agencies are being challenged through severe street protests. Many times these acts stand antinomies to democracy. Rise of various interest groups and non-state-actors, on the other hand, have further aggravated problems as their activities are maintaining permanent nature of revolutionary political culture with strategy of what Gramsci had called the movement of war maneuvered. Professional political elites (political entrepreneurs), for their part, are found to have been exploiting state and its agencies in the name of democracy and peace. Such construction in political and social behavior poses threat to political stability. This chapter discusses the post-2006 politics and argues that regime change in Nepal has failed to work as per the spirit of popular movement which envisaged peaceful, prosperous, and politically stable Nepal. Ongoing political process, in contrast, is occupied by power politics where the agendas of 'people' at large are rarely discussed. Democracy, whose Nepali equivalent translation has now become Loktantra (which used to be known by the name of Prajatantra in the past) is reinforcing neo-patrimonial culture (Bhatta, 2014)."

The most of the literatures have focused on the Maoist armed conflict as a key phenomenon in Nepali history and as a generalized notion on Nepali way of peace process. Literatures either have borrowed western model of alternative dispute resolutions, or have lobbied for modernizing conflict resolution process in Nepal. They have missed to explore the success stories of our past and indigenous practices through the comparative-historic approaches and writings. It is always very important to have comparative-historic analysis for a long standing independent nation-state with rich civilization history. When the literatures, writings and scholarships focus on the recent trend only, that undermines the existence of the history, which ultimately weakens the sovereign knowledge base and the indigenous epistemologicalconcerns. Onlyrelyingontheimportedworldviewsand theoretical paradigm ultimately ignores the local, cultural and historical roots.

\section{Peace research and peace studies in Nepal}

Nepal is rich in history of peace enlightenment, speeches and practices since ancient time through the presence of many saints, religious leaders, and philosophers. An enlightened intellectual Gautam Buddha was born in Nepal about 2500 years ago. From ancient time, Nepal has connection with the word "Peace". In Bharatbarsha literatures, Nepal has been praised as the land for knowledge generation and intellectuals. If we consider the modern day education system, Nepal has very recent history of "western model education system'. That does not mean we don't have local knowledge production system. The first university Tribhuvan University was established in 1956 AD in Kathmandu. At the beginning days, 
the university was offering major conventional social sciences subjects under the faculty of social sciences. The peace study was simply a chapter or section inside larger political science discipline.

After the signing of Comprehensive Peace Accord in 2006, much academic and nonacademic peace related courses were offered in Nepal. The oldest and largest university of Nepal, Tribhuvan University started Masters in Conflict, Peace and Development Studies (CPDS), in the Faculty of Humanities and Social Sciences. Prof. Dr. Ramesh Raj Kunwar, the then Dean of the Faculty of Humanities and Social Sciences at Tribhuvan University led the curriculum development team and commenced the graduate course in 2007 as a separate peace studies department. Though, in Nepal, 'peace studies' is not a stand-alone discipline, peace has been always attached with conflict,

security, development, Buddhism, or politics. After 2009, several other academic programs were initiated at various institutions. In 2009, 'Peace and Conflict Studies' as an international semester course offered by the Norwegian organization Kulturstudier and the Oslo Metropolitan University, in partnership with Pokhara University was started. After the establishment of a new university in 2010, Mid-Western University introduced Bachelors and Masters in Conflict and Peace Studies. In 2013, Lumbini Boudhist University started School of Buddhism and Peace Studies at Bacherlor's and Master's level. Nepal Armed Police Force in collaboration with Tribhuvan University started Masters in Security, Development and Peace Studies (MSDPS) in 2015 as part of the staff and command college course where Prof. Dr. Ramesh Raj Kunwar was lead and coordinator for the curriculum development team. At the moment, more than 15 academic programs teach Peace Studies as part of their courses and facilitate research activities in Nepal. If we look into the syllabus and curricula of the university courses, the main issues for peace studies and research in Nepal are concerned with armed conflict, violence, non-violence, social harmony, transitional justice, human security, human rights, gender, indigenous and ethnic issues.

Beside the academic achievements, many civil society and peace research activities were conducted in Nepal since 2001. Various researches and projects were conducted by multilateral organizations such as United Nations, World Bank, Asian Development Bank, and bilateral organizations such as JICA, GiZ, USAID, DFID. International NGOs were also involved in conducting peace research activities such as The Asia Foundation, Nepal Transition To Peace, Search for Common Ground, International Alert, and Care Nepal. Few civil societies groups are active in peace research and promoting peace studies in Nepal. The Non-violent Communication Practice Group in Kathmandu (since 2014), Peace and Conflict Studies Center (PCSC) (Since 2006), Asian Academy for Peace, Research and Development (Since 2010), Nepal Centre for Contemporary Research (NCCR) and Nepal Peacebuilding Initiative (NPI) are few examples. Peace researchers from Nepal are also active at International Peace Research Association (IPRA) and Asia-Pacific Peace Research Association (APPRA) like organization. Rajib Timalsina from Tribhuvan University convened Asia-Pacific Peace Research Association Conference in 2015 where 161 peace researchers from around the globe participated and presented their research papers. 
Besides all of these efforts, the understanding of the terms 'peace' and 'conflict' are found very limited. In 2018, the author was in Salyan district with graduate students of Tribhuvan University for the research field trip. The students were trying to explore how conflict and peace had been understood in the local community. Students approached almost 35 respondents in 2 days. Surprisingly, all of the respondents answered at first 'Maoist Armed conflict' when they hear the word conflict. Similarly, the respondents started to explain aftermath of Maoists Armed conflict and the political instability around the constitution drafting process in response to the question, how they had understood the term peace. The public psyche and the general publics seem influenced by the current debates of national politics. The author also has an observation notes from academia. In 2018, Prof. Dr. Ramesh Raj Kunwar and the author were in a team to conduct the entrance exam interviews for the enrollment at Tribhuvan University's masters program. Total 17 students were asked, "What do you understand by the term 'peace' in Nepali context?" Surprisingly, all the respondents replied their answers with reference to armed conflict of 1996-2006.

It was very much surprising. No respondents talked about the historical, cultural, and traditional root of conflict and peace in their society. Their influences and understanding are possibly coming from the everyday media reports, or the way they were trained by civil society organization and academic schooling. It reflects how peace is taught by many courses and trainings in Nepali community.

\section{Conclusion}

This paper has mainly three main components: analyzing the various definitions of peace, examination of the literatures depicting Nepal's peace process, and the evolution of peace studies in Nepal. Most of the definitions of oriental societies are very inclusive and broader where they envision cosmic, cosmological, nature and social order to ensure safety, justice, and happiness for both living and non-livings. In definitions from occidental part, peace denotes the simultaneous presence of many desirable states of mind and society, such as harmony, justice, equity, and so on particularly focusing on intra-personal feeling, inter-personal relationships, individual freedom, love, happiness and absence of violence. In religious perspectives, violence component has been justified to achieve peace and in post-modern writing, the focuses are on social justice and humanitarian ground to define peace.

In literatures related to conflict and peace in Nepal, youths are often presented in binary scopes: either very vulnerable who need protection, or agent of violence. Our curriculums and policies have recognized peace as an important subject matter, but there's lack of resources and trained educators. The indigenous and local cultural practices regarding to conflict and peace studies in Nepal are under-researched. Most of the publications from recent time have focused on the armed conflict 1996-2007 and the peace process in the aftermath to talk about 'peace' or 'conflict' in Nepal. The trend has already established 'Maoist armed conflict' and the 'peace process envisioned by peace accord of 2006 as the generalized version of the Nepal. Though the evolution of the idea of peace is dated back 
to ancient period, the Nepali academia and peace researchers have missed to produce contextual scholarships through the comparative-historic indigenous writings. This country provides an interesting case study for peace research from the historic time. Though the peace studies in university curriculum are recent development, the understanding, maintaining and teaching of peace has been age old phenomenon. The limited perspectives to explain peace through only recent armed conflict and conflict resolution practice should be broadened to make it inclusive of Nepal's rich culture, historical upheavals, and community based age-old public insights on peace.

\section{References}

Armstrong, J. S. (1974). Eclectic Research and Construct Validation. In Sheth, Jagadish N. (ed.) (1974). Models of Buyer Behavior: Conceptual, Quantitative, and Empirical. (pp. 3-14). New York: Harper and Row.

Barash, D. P. \& C. Webel (2018): "The Meanings of Peace" in Peace and Conflict Studies . New Delhi : Sage Publications, Chap. 1, pp. 3-12 (10 p.). Online Link : https://uk.sagepub.com/sites/default/files/upm-binaries/82890 Chapter_1 \%284\%29.pdf.

Bhatta, C. D. (2014). Antinomies of Democracy and Peace in Nepal. In P. Upadhyaya \& S. Kumar (Eds.), Peace and Conflict: The South Asian Experience (pp. 177-199). Foundation Books. doi:10.1017/9789384463076.013

Galtung, J. (1996). Peace by Peaceful Means: Peace and Conflict, Development and Civilization. London: Sage Publications.

Galtung, J. (1969). Violence, peace, and peace research. Journal of Peace Research, 6(3), 167-191.

Gandhi, M. K. (1938). Hind Swaraj or Indian Home Rule. Ahmedabad: Jitendra T. Desai. International Alert. (2019). What is Peace?. Retrieved from https://www. international-alert.org/what-we-do/what-is-peace. Accessed on 2020 September 7.

Kunwar, R. R. (2018). Editorial. Journal of APF Command and Staff College. 1 (1). DOI: 10.3126/japfcsc.v1i1.26704.

Kunwar, R. R. (2015). Cultural tourism. Journal of Tourism and Hospitality Education. 5(1). 1-57.

Kunwar, R. R. (2010). Tourists \& Tourism: Science and Industry Interface. Kathmandu: Gangasen Kunwar.

Mallik, V. (2013). Local and Community Governance for Peace and Development in Nepal. Retrieved from https://www.die-gdi.de/uploads/media/Studies 75.pdf. Accessed on 2020 July 25.

Nepal Institute for Policy Studies (2013). Nepal's Peace Process: A Brief Overview. Retrieved from https://issat.dcaf.ch/download/111494/2023947/Nepal's\%20 Peace\%20Process_A\%20Brief\%20Overview Eng\%20(2).pdf. Accessed on 2020 July 24. 
Nepal Rastra Bank (2020). Collection of Nepal's Monetary Policy 1990-2020 Part-I \& Part-II. Kathmandu: Nepal Rastra Bank.

Peace Direct (2019). Nepal Conflict profile. Retrieved from https://www.peaceinsight.org/ conflicts/nepal/. Accessed on 2020 July 24.

Pye, L. W. (1985). Asian Power and Politics: The Cultural Dimension of Authority. Cam bridge: The Belknap Press.

Royce, A. (2009). A Definition of Peace. Peace and Conflict: Journal of Peace Psychology. 10(2). 101-116. DOI https://doi.org/10.1207/s15327949pac1002_2.

Shaikh, T. (2016). "11 Different Meaning of 'Peace"”. Retrieved from https://www.huff ingtonpost.com/tami-shaikh/11-different-meanings-of- b 8652324.html? guccounter=1. Accessed on 2018 December 26.

Shrestha, R., and Bert J. (2019). Understanding Youth Political Violence in Nepal. Millenial Asia. 10 (1). 56-75. DOI: 10.1177/0976399619827118.

Timalsina, R. (2017). Consensus Modality in Nepal's Transition: Accommodating Parties and Shrinking Democratic Spaces. Asian Journal of Peacebuilding.5(1): 67-88.

Upreti, B. (2009). Resource Conflicts and Conflict Resolution in Nepal. Mountain Research and Development. 24. 60-66. DOI NO. 10.1659/0276-4741(2004)024[0060:RCACRI]2.0.CO;2. 